\title{
THE ROLE OF PLANTS IN EXPERIMENTAL BIOLOGICAL RECLAMATION IN A BED OF FURNACE WASTE FROM COAL-BASED ENERGY
}

\author{
Kazimierz H. Dyguś ${ }^{1}$ \\ 1 Faculty of Ecology, University of Ecology and Management, 12 Olszewska Str., 00-792 Warsaw, Poland, e-mail: \\ dygus@wseiz.pl
}

Received: 2014.08 .28

Accepted: 2014.10.17

Published: 2015.01.02

\begin{abstract}
In the model experiment, an assessment of the role of plants in the reclamation of the bed of combustion waste from coal-based power plants fertilised with compost and sewage sludge. The bed of combustion waste was stored in cylindrical containers with a diameter of $80 \mathrm{~cm}\left(0.5 \mathrm{~m}^{2}\right.$ of surface $)$ and the height of $100 \mathrm{~cm}$. The first stage of the experiment was carried out in 2006-2007. Then the bed was fertilised with four types of compost and sewage sludge, and then seeded with four species of grasses and white mustard. The second stage was undertaken in 2011-2013. In 2011, mixture of four species of grasses and white mustard was seeded on the same bed. It was assumed that the continuation of research in the second stage, whose results of are presented in this paper, will show a broader spectrum of vegetation changes, what will accurately track the process of biological reclamation of the bed of combustion waste. The aim of the study was to evaluate the effectiveness of reclamation in the experiment, based on the percentage estimates of the coverage of species and crop yields. During the three-year (second stage) experiment 78 species of self-seeding plants belonging to 19 taxa in the rank of families and 11 syntaxonomic groups were recorded. The most numerous were the families: aster family, grass family, papilionaceous family, goosefoot family and cabbage family. Among the syntaxonomic groups the dominating species belonged to the class Stellarietea mediae, Molinio-Arrhenatheretea and Artemisietea vulgaris. Among the forms of life hemicryptophyte and therophytes were the most represented. Highest total yields of plants were found in model containers with Complex compost and Radiowo compost and the model of sewage sludge. Based on the estimated models in each degree of coverage of species and crop yield, the highest reclamation efficiency was demonstrated in the models of reclamation of composts Complex and Radiowo, as well as in the model of sewage sludge. The lowest efficiency was demonstrated in models of composts ZUSOK and plant composts.
\end{abstract}

Keywords: model experiment, biological reclamation, flora and vegetation, crop plant, furnace waste of coal-based power plant, compost, sewage sludge.

\section{INTRODUCTION}

Landfills of coal-based power plants, due to their fine grain structure manifest high susceptibility to wind and water erosion. Technical ways of fixing this type of landfills do not eliminate the nuisance of dust. Properly selected and sown plant species can form continuous vegetation cover on the surface of landfills, and thus protect the landfill from the erosive action of wind and water, migration of heavy metals into groundwa- ter and improve the aesthetics of the landscape [Siuta 2005, Antonkiewicz, Radkowski 2006].

Biological reclamation of landfill furnace, with the use of deposits of soil formation and vegetation, is more and more often used and improved [Hryncewicz et al. 1972, Żak 1972, Wysocki 1984, 1988, Siuta 2002, Dyguś et al. 2012]. For this purpose, there have been many experimental studies (model, lysimeter, field) [Kozłowska 1995, Siuta et al. 1997, Siuta 2005, Siuta, Kutla 2005, Siuta et al. 2008, Klimont 2011]. 
Methods of biological reclamation of land resources require large amounts of humus and significant financial resources. Initiating the process of soil formation to obtain appropriate habitat conditions for the growth and formation of plant cover is a cheaper solution. For this purpose, organic fertilizers are used, due to their high nutrient and cariogenic substance content. They are mainly sewage sludge, compost, municipal waste, peat, etc. The introduction of these substances onto the surface layer of furnace ashes initiates biological life and soil formation process, facilitating conditions for the development of plants. Organic matter forms an absorbing complex for nutrients and water [Gilewska 1999, Gilewska, Przybyła 2011, Polkowski, Sulek 1999, Siuta 2005, Siuta 2007, Siuta et al. 2008, Klimont 2011].

Appropriately conducted reclamation generates favourable conditions for the formation of the vegetation cover consisting of agronomically introduced and spontaneously grown reclamation plants [Góral 2001]. The plants which are most useful in reclamation Góral [2001] enumerates species of the families papilionaceous family and crossed cabbage family, in case of the use of sewage sludge; on the other hand, when composts are used a similar role can be played by segetal weeds of the family from goosefoot family and some taxa from the group of ruderal plants.

The aim of the study was to evaluate the effectiveness of reclamation on an experimental bed of combustion waste fed with several types of nutrients. This assessment was obtained on the basis of the percentage coverage of species and estimate crop yields and ecological characteristics of plant species.

\section{MATERIALS AND METHODS}

The richness of species and plant yield was studied on the model bed ash from the heat and power plant Kawęczyn. The deposits were stored in cylindrical containers with a diameter of $80 \mathrm{~cm}$ $\left(0.5 \mathrm{~m}^{2}\right.$ area) and a height of $100 \mathrm{~cm}$ (Figure 1).

Model deposits had the following chemical composition:

- main ingredients: $\mathrm{SiO}_{2}-48,5 \% ; \mathrm{Al}_{2} \mathrm{O}_{3}-$ $4,8 \% ; \mathrm{Fe}_{2} \mathrm{O}_{3}-2,8 \% ; \mathrm{CaO}-2,8 \% ; \mathrm{MgO}$ $-2,7 \% ; \mathrm{K}_{2} \mathrm{O}-2,1 \% ; \mathrm{TiO}_{2}-1,1 \% ; \mathrm{Na}_{2} \mathrm{O}-$ $0,8 \% ; \mathrm{MnO}_{2}-0,5 \%$;

- heavy metals, in mg/100g: $\mathrm{Zn}-90 ; \mathrm{Cu}-59$; $\mathrm{Pb}-50 ; \mathrm{Ni}-42 ; \mathrm{Co}-17$; $\mathrm{Cd}-15 ; \mathrm{Cr}-46$.

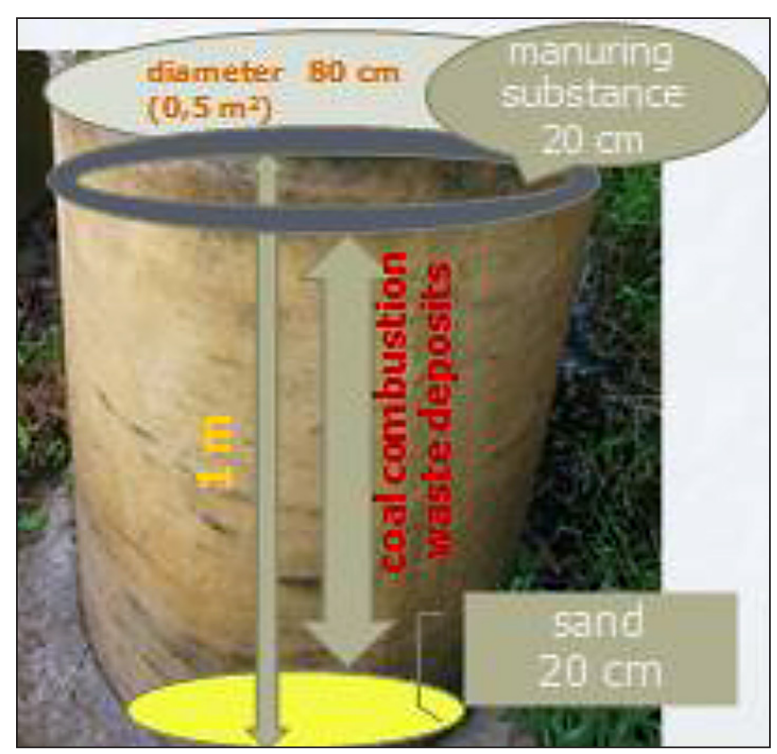

Figure 1. The construction and dimensions of an experiment container

The containers with waste deposits were fertilized with following substances:

- experimentally produced plant compost from green municipal waste (kr) [Madej 2007, Madej et al. 2010];

- „Radiowo" compost from non-selectively collected municipal waste (kRa);

- compost from municipal waste processing plant - Zakład Unieszkodliwiania Stałych Odpadów Komunalnych „ZUSOK” (kZ);

- $\mathrm{AG}$ - COMPLEX compost made from green municipal waste from Warsaw $(\mathrm{kC})$ [Opaliński 2007];

- $\quad$ sewage sludge from Radzymin plant (O);

- Mineral fertiliser $\mathrm{N}, \mathrm{P}_{2} \mathrm{O}_{5}, \mathrm{~K}_{2} \mathrm{O}$ (NPK).

For one variant of the experiment there were six containers, two for each of the three doses of nutrients (single, doubled and tripled) (Figure 4-6).

The scheme of the experiment and reclamation dose of fertilizers is presented in Table 1, and their characteristics in Table 2 [Siuta et al. 2008].

The first stage of the experiment was carried out in 2005 and 2006 [Siuta et al. 2008]. In 2007-2010, plant vegetation and soil formation proceeded without any interference.

Prior to the second stage of the experiment (2011-2013) ground (dry) mass of the plant was removed, leaving the root part. In the spring of 2011. mixture of four grass species was seeded: perennial ryegrass var. Stadion, smooth meadow-grass var. Evona, tall fescue var. Starlett, red fescue var. Maxima and one species of dicotyledonous plant - 
Table 1. Reclamation dose of fertilizers

\begin{tabular}{|c|c|c|c|c|c|c|}
\hline Substances introduced & \multicolumn{6}{|c|}{ Doses } \\
\hline & \multicolumn{3}{|c|}{$\mathrm{dm}^{3} / 0.5 \mathrm{~m}^{2}$} & \multicolumn{3}{|c|}{$\mathrm{m}^{3} / \mathrm{ha}$} \\
\hline Sewage sludge (O) & 5.0 & 10.0 & 15.0 & 100 & 200 & 300 \\
\hline Plant compost (kr) & 5.0 & 7.5 & 10.0 & 100 & 150 & 200 \\
\hline Radiowo compost (kRa) & 5.0 & 7.5 & 10.0 & 100 & 150 & 200 \\
\hline ZUSOK compost (kZ) & 5.0 & 7.5 & 10.0 & 100 & 150 & 200 \\
\hline Complex compost (kC) & 5.0 & 7.5 & 10.0 & 100 & 150 & 200 \\
\hline NPK & \multicolumn{3}{|c|}{$\mathrm{g} / 0.5 \mathrm{~m}^{2}$} & \multicolumn{3}{|c|}{$\mathrm{kg} / \mathrm{ha}$} \\
\hline Nitrogen $(\mathrm{N})$ & 7.5 & 10.0 & 12.5 & 150 & 200 & 250 \\
\hline Phosphorus $\left(\mathrm{P}_{2} \mathrm{O}_{5}\right)$ & 3.5 & 4.5 & 6.0 & 70 & 90 & 120 \\
\hline Potassium $\left(\mathrm{K}_{2} \mathrm{O}\right)$ & 5.0 & 7.5 & 10.0 & 100 & 150 & 200 \\
\hline Total NPK & 16.0 & 22.0 & 28.5 & 320 & 440 & 570 \\
\hline
\end{tabular}

Table 2. Properties of organic fertilizers used in the experiment

\begin{tabular}{|l|c|c|c|c|c|}
\hline \multirow{2}{*}{ Properties } & \multicolumn{5}{c|}{ Type of fertilizer } \\
\cline { 2 - 6 } & $\begin{array}{c}\text { Radiowo } \\
\text { compost (kRa) }\end{array}$ & $\begin{array}{c}\text { Plant } \\
\text { compost (kr) }\end{array}$ & $\begin{array}{c}\text { ZUSOK } \\
\text { compost (kZ) }\end{array}$ & $\begin{array}{c}\text { Complex } \\
\text { compost (kC) }\end{array}$ & $\begin{array}{c}\text { Sewage } \\
\text { sludge (O) }\end{array}$ \\
\hline Organic substances content in d.m., \% & 25.8 & 42.8 & 24.0 & 74.4 & 37.7 \\
Organic carbon content in d.m., \% & 12.8 & 19.3 & 11.9 & 39.2 & 21.2 \\
Nitrogen content in d.m., \% & 1.1 & 2.1 & 1.0 & 5.8 & 1.4 \\
Phosphorus content in d.m., \% & 0.6 & 0.8 & 0.5 & 1.5 & 0.6 \\
Potassium content in d.m., \% & 0.5 & 1.0 & 0.8 & 0.3 & 1.3 \\
C : N & 10.8 & 9.2 & 11.9 & 6.1 & 15.1 \\
pH & 7.8 & 7.2 & 7.9 & 7.1 & 7.9 \\
Fresh substances, g/dm ${ }^{3}$ & 807 & 330 & 790 & 950 & 490 \\
Dry substances, g/dm & 472 & 219 & 504 & 185 & 350 \\
Water content, \% & 40.1 & 31.7 & 36.9 & 80.9 & 40 \\
Nitrogen content, gN/dm ${ }^{3}$ & 5.2 & 4.6 & 5.0 & 11.0 & n.o. \\
\hline
\end{tabular}

n.o. - not determined.

white mustard (Figure 2). After sowing the plants the model deposits were fed with a complex mineral fertilizer (Azofoska) containing 13.6\% of nitrogen, $6.4 \% \mathrm{P}_{2} \mathrm{O}_{5}, 19.1 \% \mathrm{~K}_{2} \mathrm{O} 4.5 \% \mathrm{MgO}$ and $23.0 \%$ $\mathrm{SO}_{3}$ with low $\mathrm{Cu}, \mathrm{Fe}, \mathrm{Mn}$, Mo and $\mathrm{Zn}$ content.

In the growing seasons of Stage II of the experiment detailed observations of the flora were carried out. The listed plant species were analyzed for floristic and phytosociological, taxonomic and ecological characteristics. Three-year dynamics of plants changes in containers during the multi-variant experiment were expressed as the percentage share of cover crops in different experimental models. Based on the species composition of plants, systematic, syntaxonomic, ecological, geographical and historical groups were distinguished, and the forms of life by Raunkiaer and environmental indicators according to Ellenberg were described. Over the three years of the experiment, each month during the vegetation pe- riod the species inventoried and their percentage of coverage was determined.

Three times a year (in June, August and October) plants crops were harvested (Figure 3). The collected plant biomass was dried in a drying

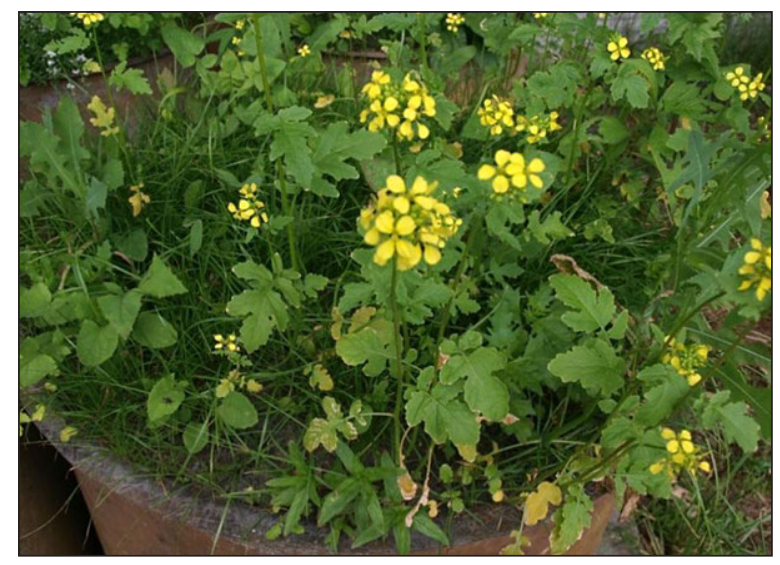

Figure 2. A container with vegetating grass and white mustard 


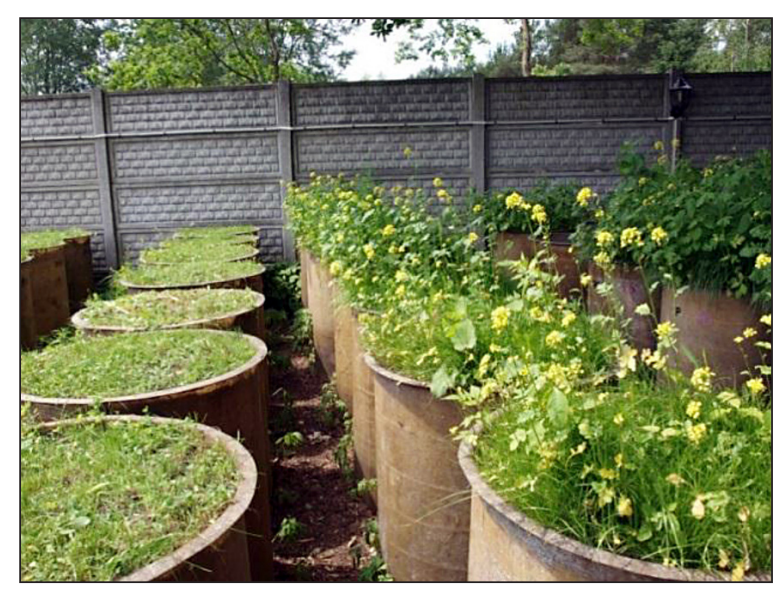

Figure 3. The row of containers with grass and white mustard (Sinapis alba) during the first year of experience (on the right); containers on the left after plants crop harvesting

oven SLW STD INOX 240 at $75^{\circ} \mathrm{C}$, to obtain a dry mass, and then weighed to $0.0001 \mathrm{~g}$ on a laboratory scale Radwag XA 310.

The flora underwent ecological analysis (Table 3). Taxonomic data was compiled according to "The key to determine of vascular plants in Polish lowlands" [Rutkowski, 1998]. The names of the syntaxonomic groups according to Matuszkiewicz was used [2001]. Classification and share of flora life forms according to Raunkiaer was used [Zarzycki et al. 2002]. Geo-historical analysis of the plants was based on the studies by Rutkowski [1998] and Mirek et al. [2002]. The average coverage of plants with the models of fertilization were presented in a Braun-Blanquet scale (1964), including the modifications by Westhoff and van der Maarel (1978).

Latin names of vascular plants was used according to Mirek et al. [2002].

\section{RESULT AND DISCUSSION}

\section{Ecological analysis of the flora}

In 2011-2012, 67 species of plants were found in the containers, among them as many as 62 species which settled spontaneously. In 2013, the number of spontaneous species rose to 78 . The floristic composition of plants has proven useful in assessing the effectiveness of reclamation sites. The abundance of plants species and their coverage on the surface of the containers were analyzed. The number of species and their coverage are important indicators of the reclamation efficiency of the applied fertilizers [Gutkowska,
Pawluśkiewicz 2006, Dyguś, Madej 2012, Dyguś et al. 2014]. It is worth mentioning that in the process of biological reclamation, proper selection of plants is important [Majtkowski et al. 1999, Nowak 2006]. The flora inventoried in 20112012 belonged to 17 taxa, in the rank of families, among which the dominant species were members of aster family (Asteraceae), goosefoot family (Chenopodiaceae) and cabbage family (Brassicaceae). During the 2013 growing season 19 taxa in the rank of the family were reported and their families dominance structure was partially changed. Still the species of aster family dominated, but the species of the grass family (Poaceae) and papilionaceous family (Fabaceae) became subdominants (Table 4). This is due to the predominance of anemochory in these families that produce large amounts of light, volatile seeds, allowing them to spread over long distances. The most numerous botanical types include goosefoot (Chenopodium), knotweed (Polygonum), sowthistle (Sonchus), bluegrass (Poa), orache (Atriplex), clover (Trifolium), plantain (Plantago) and sedge (Carex). This is a typical distribution of botanical taxa in the spontaneous formation of the vegetation cover in the early stages of reclamation of industrial and municipal landfills [Gutkowska, Pawluśkiewicz 2006, Rostański 2006, Dyguś et al. 2012].

Phytosociological and syntaxonomic analysis of flora of the years 2011-2013 proved the presence of 11 groups in the rank of classes. Among the distinguished groups of the studied flora more than $40 \%$ of the species belonged to nitrophilous communities of cultivated fields (class Stellarietea mediae). Two further groups of species were associated with the meso- and eutrophic communities of meadows (Class Molinio-Arrhenatheretea) and anthropogenic ruderal habitats (Class Artemisietea vulgaris). Other groups were represented by negligible number of syntaxonomic species (Table 5).

The spectrum of life forms of vascular plants vascular plants was partially changed. Among the identified species in 2011-2012 a clear dominance of annual plants (therophytes) was demonstrated, which accounted for almost half of the species of the studied flora. A relatively high proportion $(39 \%)$ in the flora were perennials - hemicryptophytes. However, in 2013, hemicryptophytes clearly dominated (45\%), with a simultaneous tendency to reduce the share of therophytes. Throughout the observation period there was a 


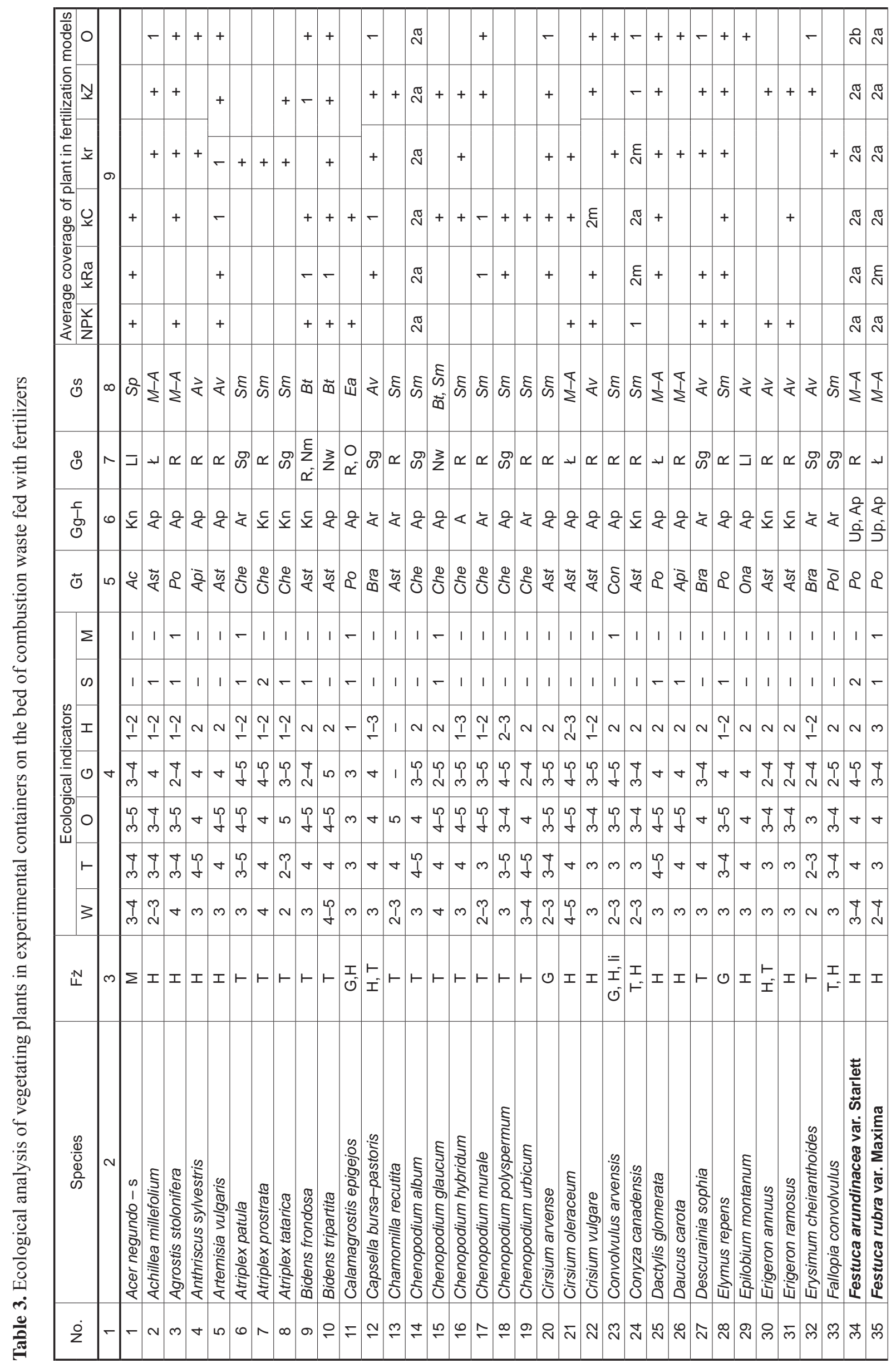




\begin{tabular}{|c|c|c|c|c|c|c|c|c|c|c|c|c|c|c|c|c|c|c|c|c|c|c|c|c|c|c|c|c|}
\hline+ & స్ + & ని & & & & $-1 \underset{\sim}{\mathcal{E}}$ & -1 & + & + & + & + & + & & तิ & + & + & + & + & & & +- & + & & & -1 & న & -1 & N \\
\hline & న & N & + & & + & స్ & + & + & + & + & $-H$ & + & + & & -1 & + & & + & & & - & + & -1 & + - & + & $\stackrel{\widetilde{N}}{\mathrm{~N}}$ & + & స్ \\
\hline+ & + & $\stackrel{\mathbb{\pi}}{\sim}$ & & & + & $+\widetilde{\sim}$ & & + & + & & +1 & + & & న & -1 & + & & & + & + & + & & + & $\stackrel{\mathbb{N}}{\sim}$ & & $\stackrel{\pi}{\sim}$ & + & \\
\hline & న + & న & & + & -1. & $\rightarrow \underset{\sim}{E}$ & & + & + & + & - & + & & $\stackrel{\sim}{\sim}$ & + & & & + & & + & $\stackrel{\curvearrowright}{\sim}$ & & -1 & + & + & $\rightarrow+$ & + & ฐ్ \\
\hline & & N & & & +8 & స్ స్ & & + & & & + & + & & N & & & & -1 & + & & $m$ & + & -1 & $+\underset{\sim}{\mathbb{N}}$ & & N + & -1 & \\
\hline
\end{tabular}

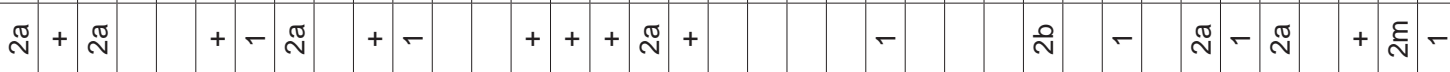

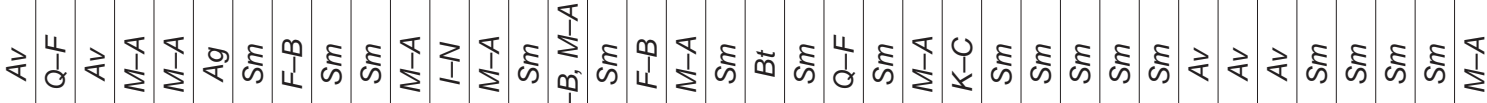

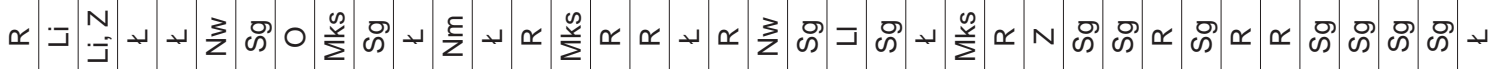

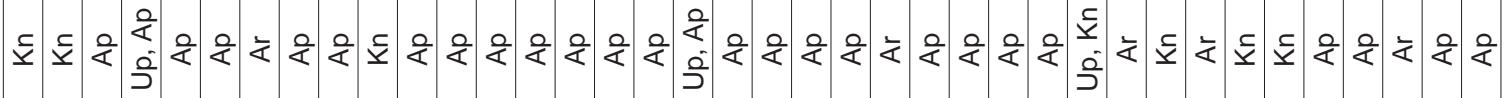

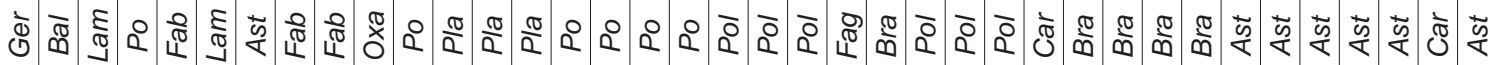

\begin{tabular}{|c|c|c|c|c|c|c|c|c|c|c|c|c|c|c|c|c|c|c|c|c|c|c|c|c|c|c|c|c|}
\hline & & & & & & & & & & & & & & & & & & & & & & & & & & & & \\
\hline & & -1 & - & 1 & | & 1 & 1 & & 1 & 1 & 111 & 1 & 1 & 1 & $\begin{array}{lll}1 & 1\end{array}$ & 1 & 11 & $\begin{array}{lll}1 & 1\end{array}$ & 1 & $\begin{array}{lll}1 & 1\end{array}$ & 욤 & 1 & 1 & 1 & 1 & & & 1 \\
\hline & & -1 & & -1 & I & 11 & 1 & & 1 & -1 & $\begin{array}{rl}-1 & 1\end{array}$ & 1 & 1. & $\rightarrow$ & $\begin{array}{lll}1 & 1\end{array}$ & 1 & 1 & $\begin{array}{lll}1 & 1\end{array}$ & 1 & $\begin{array}{lll}-1 & 1\end{array}$ & 1 효 & 1 & 1 & 1 & 1 & & 1 & \\
\hline & & & & $\stackrel{1}{\sim}$ & & I & & & $\sim$ & $m$ & 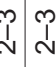 & & $\sim$ & & 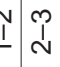 & $\sim$ & $\sim \curvearrowright$ & $v \sim$ & $\begin{array}{c}N \\
I\end{array}$ & $\sim \sim$ & 흥 & & & $\sim$ & I & N & $m$ & \\
\hline & & & & & $\dot{n}$ & 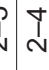 & & & $m$ & & & $\begin{array}{l}L \\
0 \\
m\end{array}$ & & $\nabla$ & 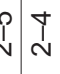 & गे & & & & $\begin{array}{ll}I \\
\text { S }\end{array}$ & : & $\begin{array}{l}\text { †े } \\
\text { (I) }\end{array}$ & & 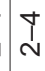 & & $\nabla$ & & \\
\hline & & $\nabla$ & & & & 虫 & & & & & $\nabla \mid \frac{L}{q}$ & $\nabla$ & $\llcorner$. & & $f \circ$ & $\diamond$ & गे ભ & & $\stackrel{m}{\sim}$ & & $f$ 용 & $\begin{array}{l}0 \\
q\end{array}$ & & & 1 & & & \\
\hline & & $\nabla$ & & & f & + & $\theta$ & & 寸 & t & & $\gamma$ & m. & + & $\begin{array}{l}d \\
m\end{array}$ & † & తે & $m$ r & & $\nabla m$ & $n$ 요 & $\nabla$ & $n$ & 1 & 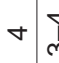 & f & & 。 \\
\hline & & & & & & $\stackrel{m}{\sim}$ & & & & & $\begin{array}{l}J_{m} \\
\sim\end{array}$ & & $\sim$ & & $m$ & $m$ & త్m & $\left.m\right|_{m} ^{+}$ & $\sim$ & mे & m 8 & & & ' & गे & & & 寸 \\
\hline & & & & & & & & & & & & & & & & & & & & & & & - & & & & & \\
\hline
\end{tabular}




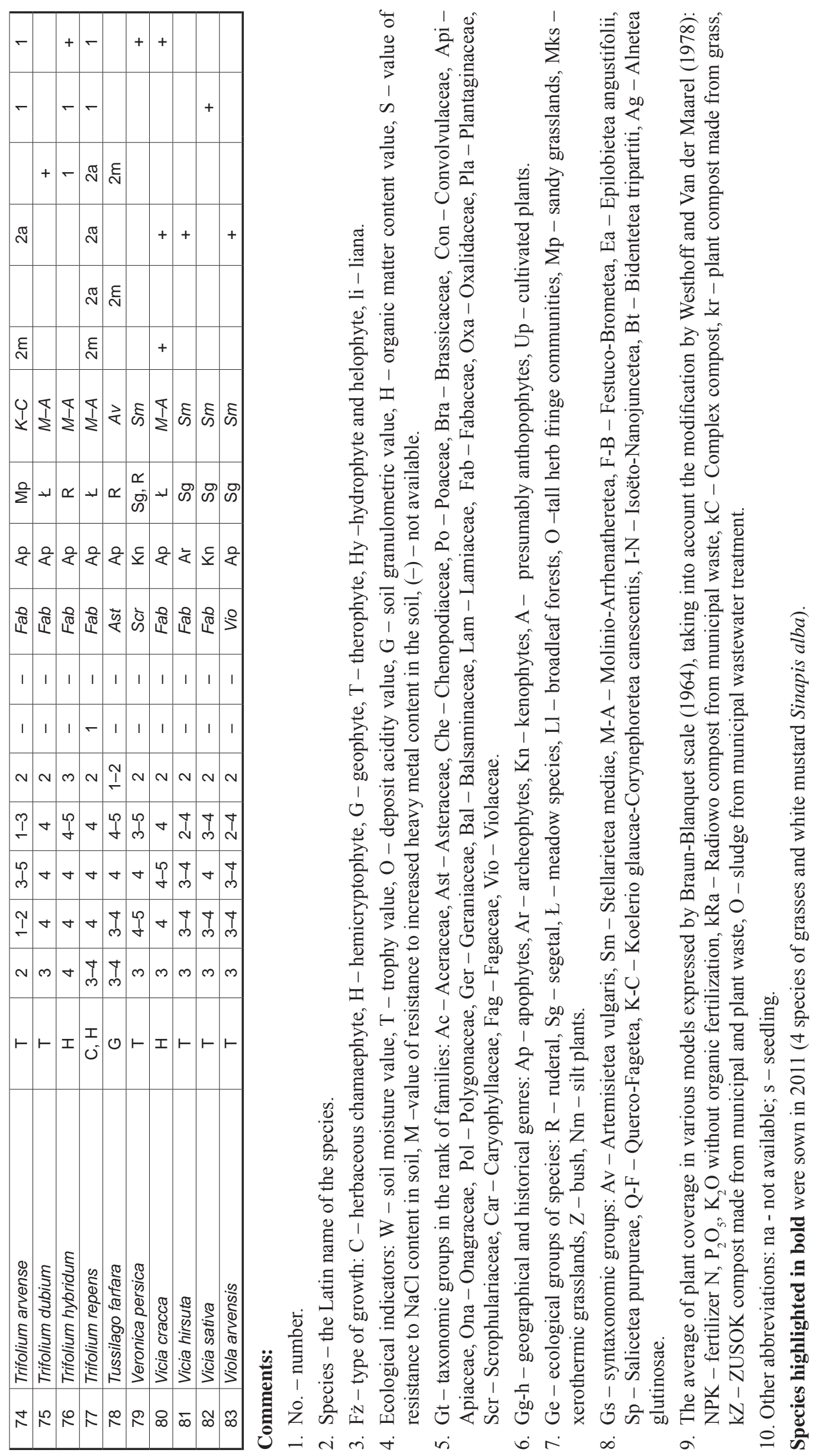


Table 4 Share of families in the flora in the third year of the model experiment

\begin{tabular}{|c|c|c|c|c|c|c|c|c|c|c|c|c|c|c|}
\hline \multirow{3}{*}{ Families } & \multirow{2}{*}{\multicolumn{2}{|c|}{ Flora total }} & \multicolumn{12}{|c|}{ Number and percentage of species in experimental models } \\
\hline & & & \multicolumn{2}{|c|}{ NPK } & \multicolumn{2}{|c|}{$\mathrm{kRa}$} & \multicolumn{2}{|c|}{$\mathrm{kC}$} & \multicolumn{2}{|c|}{$\mathrm{kr}$} & \multicolumn{2}{|c|}{$k Z$} & \multicolumn{2}{|c|}{$\mathrm{O}$} \\
\hline & number & $\%$ & number & $\%$ & number & $\%$ & number & $\%$ & number & $\%$ & number & $\%$ & number & $\%$ \\
\hline Asteraceae - aster family & 19 & 22.9 & 14 & 35.0 & 13 & 33.3 & 15 & 29.4 & 12 & 24.0 & 16 & 29.1 & 12 & 22.2 \\
\hline Poaceae - grass family & 12 & 14.5 & 11 & 27.5 & 10 & 25.6 & 11 & 21.6 & 10 & 20.0 & 10 & 18.2 & 10 & 18.5 \\
\hline Fabaceae - popilionaceous family & 10 & 12.1 & 5 & 12.5 & 3 & 7.7 & 6 & 11.7 & 5 & 10.0 & 6 & 10.9 & 6 & 11.1 \\
\hline $\begin{array}{l}\text { Chenopodiaceae - goosefoot } \\
\text { family }\end{array}$ & 9 & 10.8 & 1 & 2.5 & 3 & 7.7 & 6 & 11.7 & 5 & 10.0 & 5 & 9.1 & 2 & 3.7 \\
\hline Brassicaceae - cabbage family & 8 & 9.6 & 2 & 5.0 & 7 & 18.0 & 4 & 7.8 & 4 & 8.0 & 8 & 14.5 & 8 & 14.8 \\
\hline Polygonaceae - buckwheat family & 7 & 8.4 & 2 & 5.0 & 2 & 5.1 & 2 & 3.9 & 6 & 12.0 & 4 & 7.3 & 2 & 3.7 \\
\hline Plantaginaceae - plantain family & 3 & 3.6 & 1 & 2.5 & - & - & 2 & 3.9 & 2 & 4.0 & 3 & 5.5 & 2 & 3.7 \\
\hline Lamiaceae - mint family & 2 & 2.4 & 1 & 2.5 & - & - & 1 & 2.0 & - & - & - & - & 1 & 1.9 \\
\hline Apiaceae - carrot family & 2 & 2.4 & - & - & - & - & - & - & 2 & 4.0 & - & - & 2 & 3.7 \\
\hline Caryophyllaceae - pink family & 2 & 2.4 & 1 & 2.5 & - & - & 1 & 2.0 & 1 & 2.0 & 1 & 1.8 & 2 & 3.7 \\
\hline $\begin{array}{l}\text { Convolvulaceae - morning-glory } \\
\text { family }\end{array}$ & 1 & 1.2 & - & - & - & - & - & - & 1 & 2.0 & - & - & 1 & 1.9 \\
\hline $\begin{array}{l}\text { Onagraceae - evening-primroses } \\
\text { family }\end{array}$ & 1 & 1.2 & - & - & - & - & - & - & - & & - & - & 1 & 1.9 \\
\hline Geraniaceae - geranium family & 1 & 1.2 & - & - & - & - & - & - & 1 & 2.0 & - & - & 1 & 1.9 \\
\hline Oxalidaceae - sorrel family & 1 & 1.2 & - & - & - & - & - & - & - & - & 1 & 1.8 & 1 & 1.9 \\
\hline Balsaminaceae - balsamina family & 1 & 1.2 & 1 & 2.5 & - & - & 1 & 2.0 & 1 & 2.0 & 1 & 1.8 & 1 & 1.9 \\
\hline Scrophulariaceae - figwort family & 1 & 1.2 & - & - & - & - & - & - & - & - & - & - & 1 & 1.9 \\
\hline Violaceae - violet family & 1 & 1.2 & - & - & - & - & 1 & 2.0 & - & - & - & - & - & - \\
\hline Aceraceae - maple family & 1 & 1.2 & 1 & 2.5 & 1 & 2.6 & 1 & 2.0 & - & - & - & - & - & - \\
\hline Fagaceae - beech family & 1 & 1.2 & - & - & - & - & - & - & - & - & - & - & 1 & 1.9 \\
\hline Total & 83 & 100.0 & 40 & 100.0 & 39 & 100.0 & 51 & 100.0 & 50 & 100.0 & 55 & 100.0 & 54 & 100.0 \\
\hline
\end{tabular}

\section{Comments:}

$\mathrm{NPK}$ - fertilizer $\mathrm{N}, \mathrm{P}_{2} \mathrm{O}_{5}, \mathrm{~K}_{2} \mathrm{O}$ without organic fertilization,

$\mathrm{kRa}$ - Radiowo compost,

$\mathrm{kC}$ - Complex compost,

$\mathrm{kr}$ - plant compost,

$\mathrm{kZ}$ - ZUSOK compost,

$\mathrm{O}$ - sludge from municipal wastewater treatment.

Table 5. Participation syntaxonomic groups in the rank of classes in the third year of the experiment

\begin{tabular}{|l|c|c|}
\hline \multicolumn{1}{|c|}{$\begin{array}{c}\text { Syntaxonomic group } \\
\text { (class) }\end{array}$} & $\begin{array}{c}\text { Number of } \\
\text { species }\end{array}$ & $\%$ \\
\hline Stellarietea mediae & 35 & 42.2 \\
\hline Molinio-Arrhenatheretea & 18 & 21.7 \\
\hline Artemisietea vulgaris & 15 & 18.1 \\
\hline Bidentetea tripartiti & 4 & 4.8 \\
\hline Festuco-Brometea & 3 & 3.6 \\
\hline Koelerio-Corynephoretea & 2 & 2.4 \\
\hline Querco-Fagetea & 2 & 2.4 \\
\hline Isoëto-Nanojuncetea & 1 & 1.2 \\
\hline Epilobietea angustifolii & 1 & 1.2 \\
\hline Salicetea purpureae & 1 & 1.2 \\
\hline Alnetea glutinosae & 1 & 1.2 \\
\hline \multicolumn{1}{|c|}{ Total } & 83 & 100.0 \\
\hline
\end{tabular}

significant share $(12 \%)$ of geophytes, i.e. plants hiding their buds in the soil, often with storage organs (Table 6).

\section{Evaluation of the effectiveness of reclamation in a model experiment based on plant cover}

In the last year of the experiment in all models of fertilization, in terms of coverage, grass seeded at the beginning of the experiment dominated (Table 3 - Column 9, Figure 6 and 7). In contrast, among the self-seeding plants their presence varies between models, for example, in NPK model papilionaceous plants dominated, and in models with Radiowo and ZUSOK compost and sewage sludge aster plants had the greatest coverage. The role of the so-called reclamation plants should 
Table 6. The spectrum of life forms of plants according to Raunkiaer in the third year of the experiment

\begin{tabular}{|l|c|c|}
\hline \multicolumn{1}{|c|}{ Form of of living } & $\begin{array}{c}\text { Number of } \\
\text { species }\end{array}$ & $\%$ \\
\hline Hemicryptophytes $(\mathrm{H})$ & 37 & 44.6 \\
\hline Therophytes $(\mathrm{T})$ & 33 & 39.8 \\
\hline Geophytes (G) & 10 & 12.0 \\
\hline Megafanerophytes (M) & 2 & 2.4 \\
\hline Green chamephytes (C) & 1 & 1.2 \\
\hline \multicolumn{1}{|c|}{ Total } & 83 & 100.0 \\
\hline
\end{tabular}

also be noted. They have a high biomass level and are annuals in most cases (therophytes). Their increased participation in the coverage can be an indicator of appropriate initiation of the course of biological reclamation of landfills. It was quite clearly observed in a model of Complex compost. No less important is the role of papilionaceous plants and aster plants in the process of reclamation. Their large share facilitates the creation of the vegetation cover in most models, and therefore, the course of rehabilitation, because many species of these groups are perennials.

Experimental model with NPK without organic fertilization (NPK). In the first year of the experiment (2011). Almost half of the containers fertilized with NPK blend were occupied by the sown 4 species of grasses. In contrast, coverage of white mustard (Sinapis alba) was estimated at approx. $10 \%$. Over 20 other species of dicotyledonous plants inhabited spontaneously, incl.: white clover (Trifolium repens), Canadian fleabane (Conyza canadensis), fat-hen (Chenopodium album). In 2012, the share of grasses decreased to approx. $10 \%$, and white mustard was not found (annual plant). In comparison to 2011 an increase in the share of small balsam (Impatiens parviflora), false London rocket (Sisymbrium loeselii), fat-hen (Chenopodium album), corn sow-thistle (Sonchus arvensis), field clover (Trifolium arvense) was recorded. The total number of species increased to 30. In the third year of the experiment in containers supported with fertilizer NPK (without organic fertilization) two species of grasses, sown in 2011, were dominant: Evon smooth meadow-grass var. Evon (Poa pratensis var. Evon) and red fescue var. Maxima (Festuca rubra var. Maxima). The free surfaces were usually occupied by self-seeding black medic (Medicago lupulina). Most species belonged to therophytes, annual plants overwintering in a form of seeds. In terms of the share of families, most species belonged to aster family, grasses and papilionaceous plants. In contrast, floristic richness remained at a similar level as in 2012.

Based on the floristic observations moderate effectiveness of NPK fertilizer on the reclamation of a bed of coal combustion waste was proved. This is evident by relatively low coverage with hemicryptophytes - turf and cluster plants, mainly grasses.

Experimental model with Radiowo compost (kRa). In this model, in the first year of the experiment, 26 species of plants were recorded. The sown grasses and white mustard constituted almost $3 / 4$ of the container surfaces, approx. 50 and $25 \%$ respectively. In the second year, the number of species did not change much, but there was a qualitative change in the structure of flora. Grass cover decreased to approx. $20 \%$ in favour of some species of dicotyledonous plants. These were mainly: puff-ball (Taraxacum officinale), corn sow-thistle (Sonchus arvensis), nettle-leaved goosefoot (Chenopodium murale), fat-hen (Chenopodium album), false London rocket (Sisymbrium loeselii), hedge mustard (Sisymbrium officinale), wild radish (Raphanus raphanistrum), white clover (Trifolium repens). A total of 30 species were recorded. In the third year of the experiment in the containers with Radiowo compost (kRa) there was again an increased grass cover up to almost $50 \%$, mainly involving perennial ryegrass var. Stadium (Lolium perenne var. Stadion). The number of species did not change. In the third year of observations the cover of grasses in the containers with Radiowo compost reached $50 \%$. In addition, the surfaces of containers were covered with goosefoot plants, cabbage plants and papilionaceous plants. They were both annuals (therophytes) and perennial plants (hemicryptophytes, geophytes, rhizomous plants).

The share of plants of these taxa manifests good effectiveness of reclamation on the bed. The importance of the process of biological reclamation plant of the papilionaceous plants and cabbage plants was also noted by Góral [2001].

Experimental model with Complex compost (kC). In the first year of the experiment, 25 plant species were found in the model bed. The dominant share in the coverage surface of the containers were sown with grass species. They covered approx. $60 \%$ of the containers, and white 


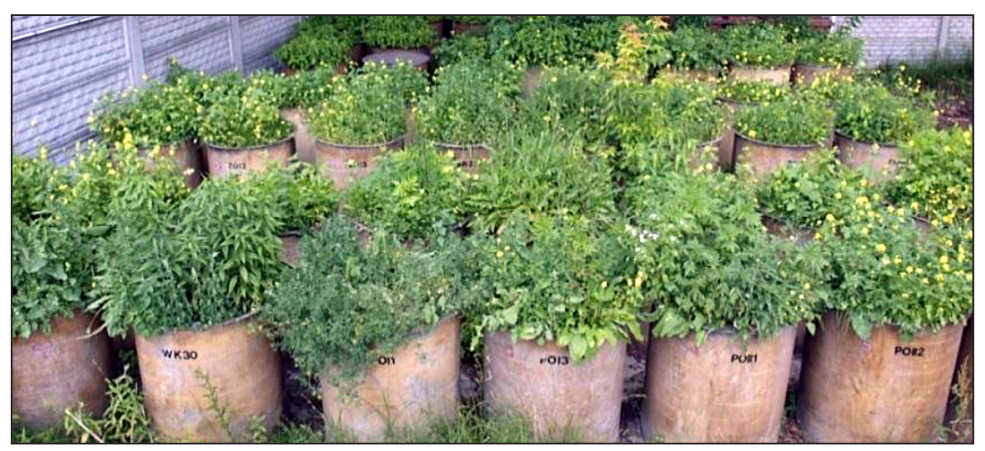

Figure 4. General view of containers with plants as on 30.05.2011

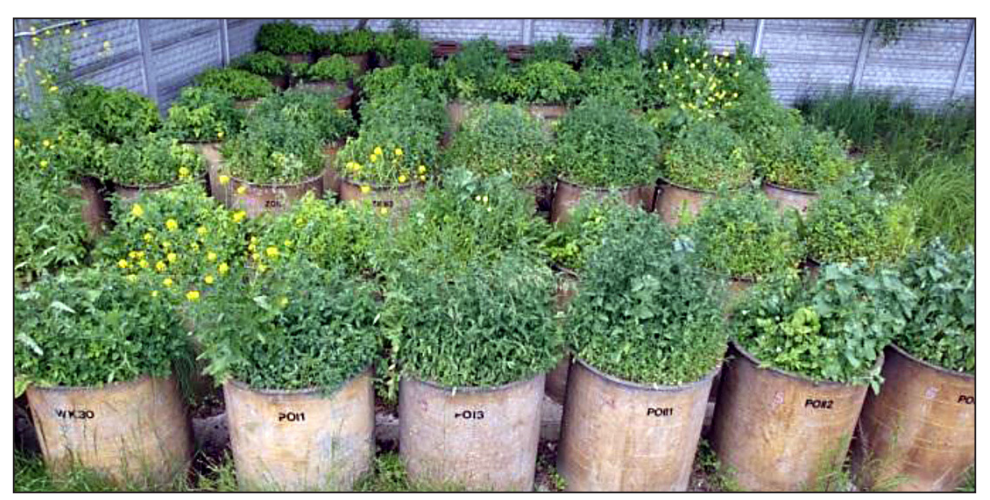

Figure 5. General view of containers with plants as on 31.05.2012

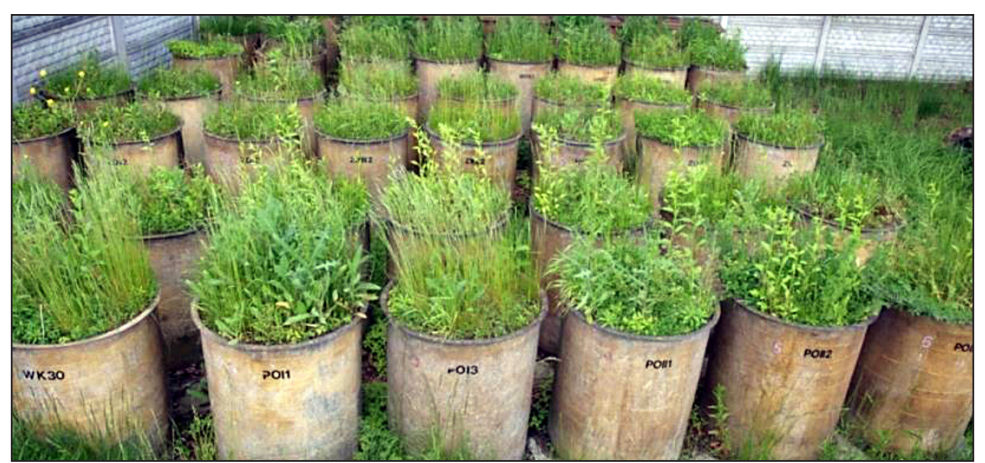

Figure 6. General view of containers with plants as on 30.05.2013

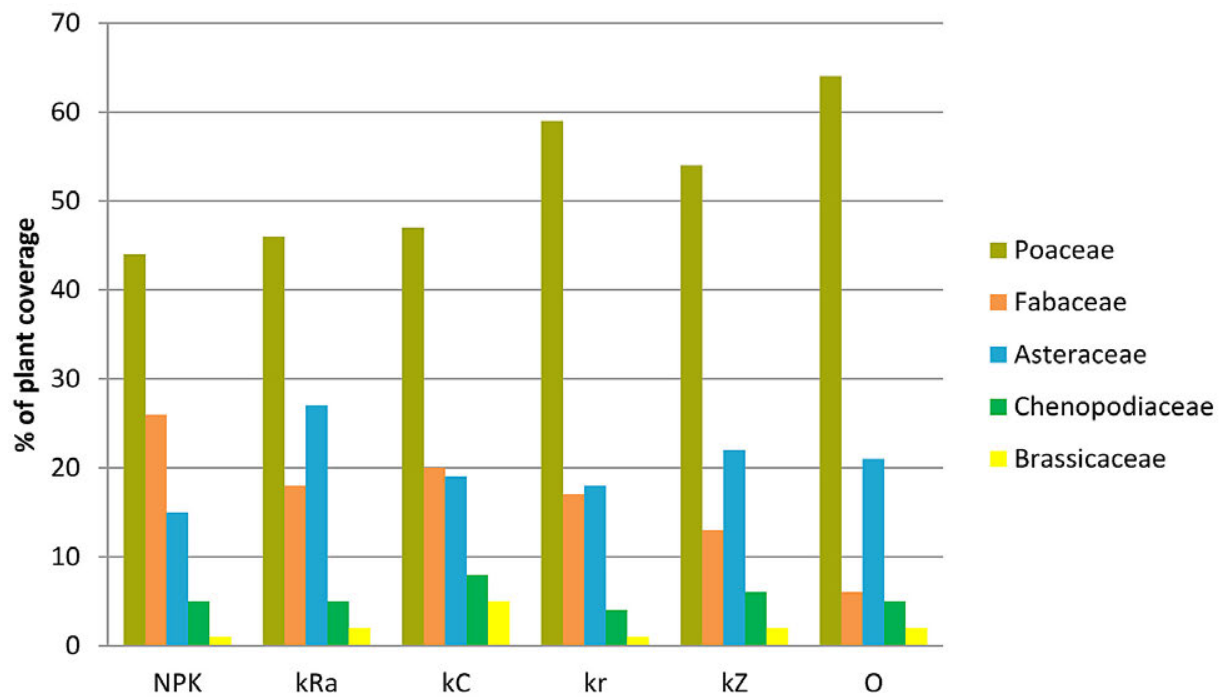

Figure 7. Percentage of dominant families in the creation of vegetation cover on the surface of experimental models after three years of the experiment 
mustard approx. $20 \%$ of the area. Other areas were spontaneously entering inhabited by several dicotyledonous plant species. In 2012, the number of species increased to 34 , and at the same time quantitative composition of plants changed radically with the participation of dicotyledonous plant species. The sown grass covered only approx. $10 \%$ of the area, without white mustard. A clear dominance of spontaneous dicotyledonous plant species was also recorded. Among them, in this model dominated: fat-hen (Chenopodium album), small balsam (Impatiens parviflora), Canadian fleabane (Conyza canadensis), white clover (Trifolium repens). More than 20 other species of small or occasional participation were recorded. In 2013, another spread of grasses (50\% of the coverage) seeded at the start of the experiment was observed. There were also some self-seeded grasses, incl.: rougle cock's-foot (Dactylis glomerata) and couch grass (Elymus repens). In total, this model 45 species of self-seeding plants were recorded. Among them, the highest surface coverage in the containers was occupied by the same species as in 2012. These were mainly therophytes: goosefoot plants, papilionaceous plants and synanthropic plant species. The domination of therophytes at this stage of recovery is not evidence of its high efficiency. Due to the relatively high proportion of grasses and goosefoot plants can one can predict for this model the intensification of soil formation in the following years and, consequently, even greater increase in the efficiency of reclamation of the applied deposit.

\section{Experimental model with plant compost} (kr). In 2011, 22 species of plants were recorded. The species of grass clearly dominated (approx. $70 \%$ coverage). In addition to the grasses there were mainly chickweed (Stellaria media), coltsfoot (Tussilago farfara) and Canadian fleabane (Conyza canadensis). In 2012, the cover of grasses decreased to $10 \%$. There was a significant expansion of dicotyledonous plant species, of which the majority were: fat-hen Chenopodium album, corn sow-thistle Sonchus arvensis, Canadian goldenrod Solidago canadensis, Canadian fleabane (Conyza canadensis). In the growing season 39 species were recorded in the containers in this model. In the following year, the third year of the experiment, more than $50 \%$ of the containers were grown with grass. For the rest of the surface more than 30 species of flowering plants were recorded, including goosefoot plants family: goosefoot plants (incl. fat-hen Chenopodium album and several species of oraches Atriplex), cabbage plants (wild mustard Sinapis arvensis, false London rocket Sisymbrium loeselii, lady's purse Capsella bursa-pastoris), papilionaceous plants (white clover Trifolium repens, bastard clover Trifolium hybridum, black medic Medicago lupulina) and synatropic plans, mainly from aster family (Canadian goldenrod Solidago canadensis, Canadian fleabane Conyza canadensis, corn sow-thistle Sonchus arvensis, puff-ball Taraxacum officinale, coltsfoot Tussilago farfara and other).

The effectiveness of recultivation in this model was partially facilitated by the inhabitation of perennial dicotyledonous (hemicryptophytes, geophytes and herbaceous chamaephytes). However, the relatively low cover of grasses at this stage of recultivation proves its slow pace.

\section{Experimental model of compost ZUSOK} (kZ). Most of the surface of the containers in this model in 2011 were overgrown with grass species (approx. 80\%) with minor contributions from white mustard. In addition, several individual self-seeding dicotyledonous plants were reported. In the next year of experiment, grasses clearly subsided, inhabiting only $20 \%$ of the area. 41 species of dicotyledonous plants were observed. Among them the greatest coverage was recorded for: small balsam (Impatiens parviflora), puffball (Taraxacum officinale), fat-hen (Chenopodium album), false London rocket (Sisymbrium loeselii) and corn sow-thistle (Sonchus arvensis). In the last year of the experiment a large share of grass cover was observed again. These were mainly grasses applied either at the beginning of the experiment, but also self-seeding species, for example: timothy grass (Phleum pratense), creeping bent (Agrostis stolonifera), annual meadowgrass (Poa annua), couch grass (Elymus repens). Among the dicotyledonous plants there were also those present in other models, typical reclamation plants. These were the plants belonging to the goosefoot family orache and goosefoot), cabbage (sisymbrium, radish and tansy mustard), papilionaceous (clover trefoil and medic). Ruderal plants, segetal weeds and meadow species had a high share of coverage.

Based on the identified floristic composition one can assume that the effectiveness of ZUSOK compost in the initial process of biological reclamation on the bed of combustion waste was 
merely satisfactory.

Experimental model of sewage sludge ( 0 ). In the first year of the experiment the surfaces of containers fertilized with sewage sludge were covered with sown grass species (more than $80 \%$ coverage) and occasionally by white mustard. The remaining 16 species were dicotyledonous plants, and among them was the greatest share common chickweed (Stellaria media). The following year, the share of grasses decreased almost threefold. These surfaces overgrown with 39 self-seeding dicotyledonous plant species, of which the predominant was: small balsam (Impatiens parviflora), corn sow-thistle (Sonchus arvensis), sickle medick (Medicago falcata), fat-hen (Chenopodium album), november goldenrod (Solidago gigantea) and common chickweed (Stellaria media). In the third year of observations grass cover increased again to over $60 \%$. During the three years of experiment in containers fertilized with sewage sludge a fairly good growth of vegetation cover was demonstrated.

It can be assumed that further stages of reclamation should be more efficient for the presence of (even with a small coverage) up to several species of papilionaceous and cruciferous family which, together with grasses, play a major role in the process of reclamation of furnace waste.

\section{Evaluating the effectiveness of reclamation in a model experiment based on the crop yield}

Based on the results of the plant yield an attempt was made to assess the efficiency of the reclamation models with fertilization. Each model was analyzed in terms of average yield of all the variants of fertilization during the three-year experiment. The size of crops in a given model was suggested by the level of effectiveness of reclamation model.

Dry matter yields of plants, in of experimental area are shown in Table 7 and graphs 7 and 8 . These data show the size of the crop yields obtained from different models of containers fertilized with three different variants (doses) of fertilizer during the three-year study.

Model N, $\mathbf{P}_{2} \mathbf{O}_{5}, \mathbf{K}_{2} \mathbf{O}$ (NPK) without organic fertilization of deposits assumed as a zero object (test), for the comparison of the effectiveness of all other types of organic fertilization. In 20112012, in variants 1 and 2 (single and a double dose of NPK) relatively high yields of plants were obtained. In the variant 3 (triple dose of NPK) plant yields were much lower than in variants 1 and 2 . However, in the last (third) one, the yield of the experiment in all variants of fertilization were found to be relatively lower (Table 7). Average total yields of plants for the period 2011-2013 from all the variants of fertilization in the analyzed model followed a clearly declining trend (Figure 8). It can be considered that the efficiency of reclamation on the basis of the yield obtained in this model was relatively low (Figure 9).

In the model of "Radiowo compost" (kRa) no clear relationship between the yields of plants and the size of reclamation dose of compost was showed. In each year of the study, the average yield of plants, regardless of the dose of fertilization with compost, had aligned values, but at the same time it was decreasing in subsequent years

Table 7. Dry matter yields obtained in 2011-2013

\begin{tabular}{|c|c|c|c|c|c|}
\hline \multirow{2}{*}{$\begin{array}{l}\text { Option } \\
\text { number }\end{array}$} & \multirow{2}{*}{$\begin{array}{c}\text { Fertilizer } \\
\text { dose }\end{array}$} & \multicolumn{3}{|c|}{ Years } & \multirow{2}{*}{$\Sigma$} \\
\hline & & 2011 & 2012 & 2013 & \\
\hline & \multicolumn{5}{|c|}{ Plant compost (model kr) } \\
\hline 1 & $10 \mathrm{dm}^{3}$ & 682 & 625 & 481 & 1788 \\
\hline 2 & $15 \mathrm{dm}^{3}$ & 887 & 442 & 323 & 1652 \\
\hline \multirow[t]{2}{*}{3} & $20 \mathrm{dm}^{3}$ & 901 & 427 & 384 & 1712 \\
\hline & \multicolumn{5}{|c|}{ ZUSOK compost (model kZ) } \\
\hline 1 & $10 \mathrm{dm}^{3}$ & 318 & 575 & 337 & 1230 \\
\hline 2 & $15 \mathrm{dm}^{3}$ & 389 & 539 & 334 & 1262 \\
\hline \multirow[t]{2}{*}{3} & $20 \mathrm{dm}^{3}$ & 572 & 607 & 337 & 1516 \\
\hline & \multicolumn{5}{|c|}{ Radiowo compost (model kRa) } \\
\hline 1 & $10 \mathrm{dm}^{3}$ & 911 & 687 & 544 & 2142 \\
\hline 2 & $15 \mathrm{dm}^{3}$ & 905 & 611 & 466 & 1982 \\
\hline \multirow[t]{2}{*}{3} & $20 \mathrm{dm}^{3}$ & 835 & 751 & 656 & 2134 \\
\hline & \multicolumn{5}{|c|}{ Sewage sludge (model O) } \\
\hline 1 & $10 \mathrm{dm}^{3}$ & 416 & 578 & 415 & 1409 \\
\hline 2 & $15 \mathrm{dm}^{3}$ & 1103 & 721 & 545 & 2369 \\
\hline \multirow[t]{2}{*}{3} & $20 \mathrm{dm}^{3}$ & 1285 & 652 & 544 & 2481 \\
\hline & \multicolumn{5}{|c|}{ Complex compost (model kC) } \\
\hline 1 & $10 \mathrm{dm}^{3}$ & 1024 & 985 & 1021 & 3030 \\
\hline 2 & $15 \mathrm{dm}^{3}$ & 1077 & 826 & 674 & 2577 \\
\hline \multirow[t]{2}{*}{3} & $20 \mathrm{dm}^{3}$ & 1735 & 1077 & 960 & 3372 \\
\hline & \multicolumn{5}{|c|}{$\mathrm{N}, \mathrm{P}_{2} \mathrm{O}_{5}, \mathrm{~K}_{2} \mathrm{O}$ (model NPK) } \\
\hline 1 & $32 \mathrm{~g}$ & 860 & 432 & 299 & 1591 \\
\hline 2 & $44 \mathrm{~g}$ & 784 & 522 & 317 & 1623 \\
\hline \multirow[t]{2}{*}{3} & $57 \mathrm{~g}$ & 427 & 304 & 298 & 1029 \\
\hline & \multicolumn{5}{|c|}{ Loam (model Z) } \\
\hline 1 & $10 \mathrm{dm}^{3}$ & b.d. & 768 & 1012 & b.d. \\
\hline 2 & $15 \mathrm{dm}^{3}$ & b.d. & 741 & 902 & b.d. \\
\hline 3 & $20 \mathrm{dm}^{3}$ & b.d. & 863 & 1171 & b.d. \\
\hline \multicolumn{6}{|c|}{ b.d. - not available } \\
\hline
\end{tabular}




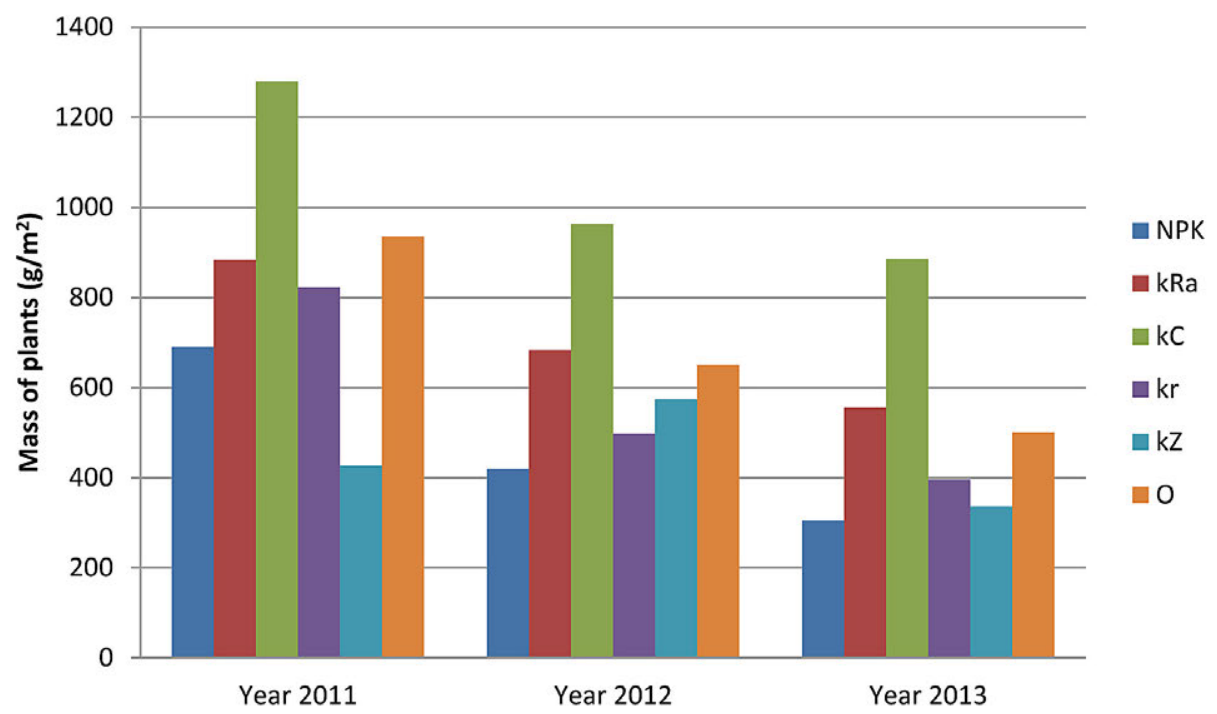

Figure 8. Average amounts of harvested plants in different forms of fertilizing in 2011-2013

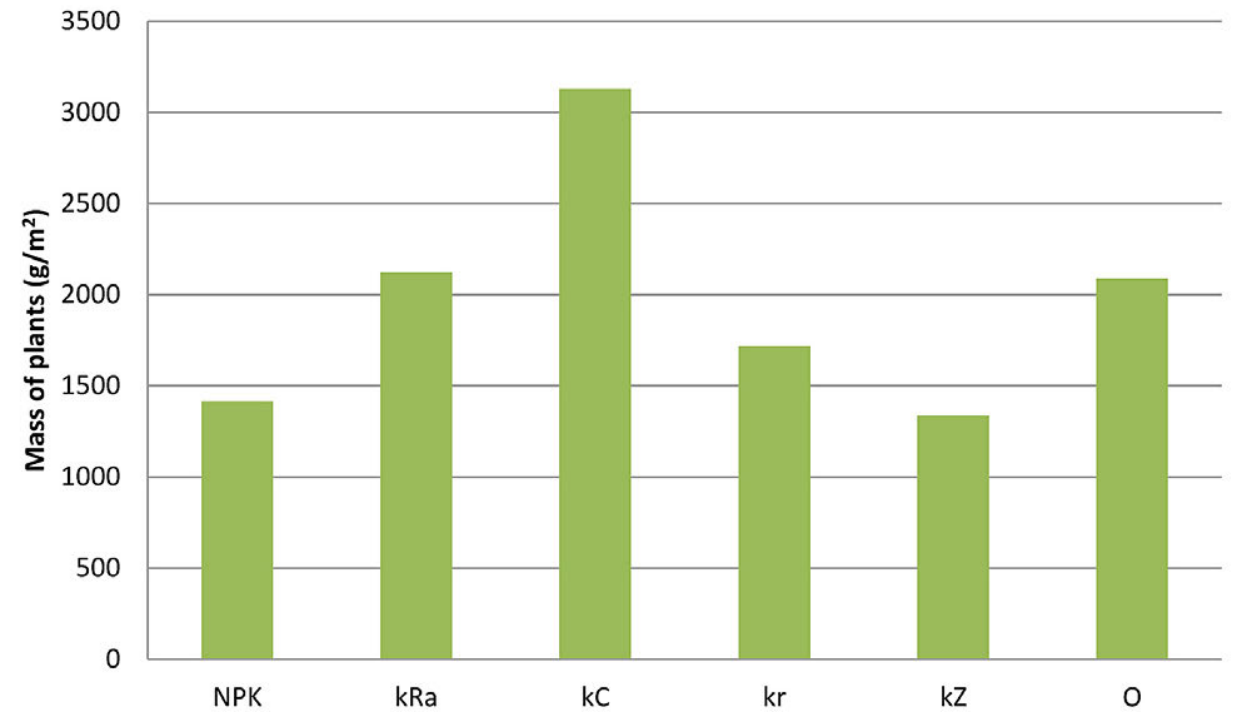

Figure 9. Evaluation of the effectiveness of reclamation on the basis of the yield of plants in containers in multi-variant experiment in bed with combustion waste

(Table 7). During the three years of the experiment in the model with Radiowo compost the total obtained crop yields decreased (Figure 8). The effectiveness of reclamation in this model, on the basis of the yield was high (Figure 9).

Three-year experiment in "Complex compost” (kC) model showed a significantly higher crop yields than in other models of fertilization. Mean total plant yield of three years and all variants of fertilization in this model were moderately decreasing (Table 7, Figure 8). Reclamation efficiency, on the basis of the results obtained in this model was very high (Figure 9).

In the first year of the experiment in a model with plant compost (kr) the highest yield of the plants was shown in variants 2 and 3. However, in the next two years significantly higher yields in the first variant and lower in variants 2 and 3 were recorded (Table 7). During the three years of experiment in the model plant with compost the aggregated crop yields decreased (Figure 8). Based on the estimation of the cumulative yield of reclamation efficiency in this model proved to be low, but the yield slightly exceeded the test model without organic fertilization - NPK (Figure 9).

In the model with ZUSOK compost (kZ) yields in 2011 were lower than in the other models. But in 2012, there was an increase in yields. However, in the third year of the experiment yields again decreased clearly (Table 7). Average total yields of plants for the period 2011-2013 from all variants of fertilization in this model 
were relatively aligned (Figure 8). The resulting low yield suggests low efficiency of reclamation in this model (Figure 9).

In 2011, the model with sewage sludge (O) gave approx. threefold higher yield in variants 2 and 3 , as compared with the first variant. A similar trend occurred in the next two years, but with lower yielding (Table 7). During the three years of experiment in the model of sewage sludge average yields of all variants decreased (Figure 8). The effectiveness of reclamation in this model, on the basis of the yield proved to be high (Figure 9).

\section{CONCLUSION}

1. The experiment on the model bed of combustion waste showed that an important role in the course of reclamation is played by the presence of appropriate forms of plant life. In the initial stage of reclamation annuals (therophytes) are important as they stimulate the process of soil formation. In further phases of reclamation they ensure the highest efficiency of grasses and dicotyledonous plants, especially biennial, and perennial (hemicryptophytes, geophytes, herbaceous chmaephytes), which perpetuate the ground.

2. During the three-year experiment a vital role in improving reclamation on the experimental fields was played (except grass) by plants of the families: aster family, goosefoot family and papilionaceous family, which gathered a large amounts of biomass, which is important in the process of reclamation.

3. Based on the estimates of the degree of coverage of species and yield reclamation in the studied models, the highest efficiency was demonstrated in containers with Complex compost and Radiowe compost, as well as in the model with sewage sludge. The lowest efficiency has been demonstrated in the models of ZUSOK composts and plant compost.

4. Weather conditions (particularly high temperatures, reduced humidity) and the depletion of nutrients in the substrate had a large influence on the experience and efficiency of reclamation in the bed of combustion waste. This illustrates the dynamics of yield decline in subsequent years of the experiment.

5. Impromptu experimental model (ex situ) of biological reclamation of furnace waste can- not refer to real systems (in situ - dumps, landfills, etc.). Its functionality is fragmented and sometimes limiting accurate conclusions. Therefore, multiple iterations and multifaceted testing is required.

\section{REFEENCES}

1. Antonkiewicz J, Radkowski A. 2006. Przydatność wybranych gatunków traw i roślin motylkowych do biologicznej rekultywacji składowisk popiołów paleniskowych. Annales UMCS, Sec. E, 2006, 61, 413-421.

2. Braun-Blanquet J. 1964. Pflanzensoziologie, Grundzüge der Vegetationskunde 3. Aufl. Springer, Vienna-Nev York, 865.

3. Dyguś K.H., Madej M. 2012. Roślinność wielowarian-towego doświadczenia modelowego na złożu odpadów paleniskowych energetyki węglowej. Inżynieria Ekologiczna, 30, 227-240.

4. Dyguś K.H., Siuta J., Wasiak G., Madej M. 2012. Roślinność składowisk odpadów komunalnych i przemysłowych. Wyd. Wyższej Szkoły Ekologii i Zarządzania, Warszawa, pp. 134.

5. Dyguś K.H., Wasiak G., Madej M. 2014. Dynamika zmian roślinności w doświadczeniu modelowym ze złożem odpadów paleniskowych energetyki węglowej. Inżynieria Ekologiczna, 40, 100-121.

6. Gilewska M. 1999. Utilization of sewage sludge in the reclamation of post-mining soil and ash disposal sites. Roczniki AR Poznań, 310. Melioracje i Inżynieria Środowiska, 20/II, 273-281.

7. Gilewska M., Przybyła Cz. 2011. Wykorzystanie osadów ściekowych w rekultywacji składowisk popiołowych. Zesz. Prob. Post. Nauk Roln. PAN, 477, 217-222.

8. Góral S. 2001. Roślinność zielna w ochronie i rekultywacji gruntów. Inżynieria Ekologiczna, 3, 161-178.

9. Gutkowska A., Pawluśkiewicz B. 2006. Kształtowanie zadarnienia i składu florystycznego zbiorowisk trawiastych pod wpływem zabiegów pratotechnicznych na składowisku popiołu EC Siekierki. Annales UMCS, Sec. E, 61, 249-255.

10. Hryncewicz J., Balicka N., Giedrojć B., Małysowa E. 1972. Badania nad utrwalaniem i zagospodarowaniem hałdy popiołowej w elektrowni „Halemba”. XIX Zjazd Naukowy PTGleb., Puławy.

11. Kozłowska B. 1995. Zastosowanie osadu ściekowego do biologicznego zagospodarowania składowisk odpadów paleniskowych. Zesz. Prob. Post. Nauk Roln. PAN, 418, 859-868.

12. Klimont K. 2011. Rekultywacyjna efektywność osadów ściekowych na bezglebowym podłożu 
wapna poflotacyjnego i popiołów paleniskowych. Problemy Inżynierii Rolniczej, 2, 165-176.

13. Madej M. 2007. Zieleń miejska źródłem surowca do produkcji kompostu. Praca doktorska, WSEiZ, Warszawa, pp. 140.

14. Madej M., Siuta J., Wasiak G. 2010. Zieleń Warszawy źródłem surowca do produkcji kompostu. Cz. II. Skład chemiczny masy roślinnej z różnych powierzchni zieleni warszawskiej. Inżynieria Ekologiczna, 23, 22-36.

15. Majtkowski W., Głażewski M., Schmidt J. 1999. Roślinność trawiasta składowiska fosfogipsów w Wiślince koło Gdańska. Fol. Uniw. Agric. Stein. 197, Agricultura 75, 207-210.

16. Matuszkiewicz W. 2001. Przewodnik do oznaczania zbiorowisk roślinnych Polski. Wyd. Naukowe PWN, Warszawa.

17. Mirek Z., Piękoś-Mirkowa H., Zając A., Zając M., 2002. Flowering Plants and pteridophytes of Poland a checklist. W. Szafer Institute of Botany, PAS, Kraków.

18. Nowak W. 2006. Rekultywacja biologiczna hałdy fosfogipsu w zakładach chemicznych „Wizów” S. A. Zesz. Nauk. Uniw. Przyr. we Wrocławiu. Ser. Rolnictwo, 88, 545, 195-203.

19. Opaliński R. 2007. Rekultywacyjna efektywność kompostu Complex na odpadach paleniskowych w doświadczeniu lizymetrycznym. Praca magisterska. WSEiZ, Warszawa, pp. 78.

20. Polkowski M, Sułek St. 1999. Kompostowanie masy roślinnej ze strefy bezleśnej przy Zakładach Azotowych Puławy. Kompostowanie i użytkowanie kompostu. IOŚ, IUNG, PTIEkol. Warszawa, 71-74.

21. Rostański A. 2006. Spontaniczne kształtowanie się pokrywy roślinnej na zwałowiskach po górnictwie węgla kamiennego na Górnym Śląsku. Wydawnictwo Uniwersytetu Śląskiego, Katowice.

22. Rutkowski L. 1998. Klucz do oznaczania roślin naczyniowych Polski niżowej. Wyd. Naukowe PWN. Warszawa.

23. Siuta J. 2002. Przyrodnicze użytkowanie odpadów. IOŚ, Warszawa.
24. Siuta J. 2005. Rekultywacyjna efektywność osadów ściekowych na składowiskach odpadów przemysłowych. Acta Agrophysica, 5(2), 417-425.

25. Siuta J. 2007. System uprawy i kompostowania roślin na składowisku odpadów posodowych w Janikowie z zastosowaniem osadów ściekowych. Inżynieria Ekologiczna, 19, 38-58 + 6 fot.

26. Siuta J., Dyguś K.H. 2013. Plony i chemizm roślin wielowariantowego doświadczenia na modelowym złożu odpadów paleniskowych energetyki węglowej. Inżynieria Ekologiczna, 35, 7-31.

27. Siuta J., Kutla 2005. Rekultywacyjne działanie osadów ściekowych na złożach odpadów paleniskowych w energetyce węglowej. Inżynieria Ekologiczna, 10, 58-69.

28. Siuta J., Wasiak G., Chłopecki K., Mamełka D. 1997. Rekultywacja efektywności osadu ściekowego na bezglebowych podłożach w doświadczeniu lizymetrycznym. II Konf. Przyrodnicze użytkowanie osadów ściekowych. Puławy-Lublin-Jeziórko, $135-154$.

29. Siuta J., Wasiak G., Madej M. 2008. Rekultywacja efektywności kompostów i osadów ściekowych na złożu odpadów paleniskowych w doświadczeniu modelowym. Ochrona Środowiska i Zasobów Naturalnych, 34, 145-172 + 26 fot.

30. Westhoff V., van der Maarel E. 1978. The BraunBlanquet approach. [In:] Classification of plant communities (ed. R.H. Whittaker), 287-297. Junk, The Hague.

31. Wysocki W. 1984. Reclamation of Alkalien Ask Piles USEPA Cincinnati. Ohio.

32. Wysocki W. 1988. Rekultywacja składowisk odpadów elektrowni węglowych. Sozologia i Sozotechnika, 26, AGH Kraków.

33. Zarzycki K., Trzcińska-Tacik H., Różański W., Szeląg Z., Wołek J., Korzeniak U. 2002. Ecological indicator values of vascular plants of Poland. W. Szafer Institute of Botany, PAS, Kraków.

34. Żak M. 1972. Wpływ powłok asfaltowych przeciwdziałających wtórnemu pyleniu składowisk popiołów lotnych na wegetację roślin. XIX Zjazd Naukowy PTGleb., Puławy. 